\title{
Skeptisisme Personal Dan Situasional Terhadap Keputusan Audit: Sebuah Studi Eksperimen
}

\author{
Rudy Suryanto, Azkia Fiki Sani, Hafiez Sofyani* \\ Fakultas Ekonomi dan Bisnis Universitas Muhammadiyah Yogyakarta \\ *email: hafiez.sofyani@umy.ac.id
}

\begin{abstract}
The study aims to examine the influence of personal and situational scepticism on audit judgement. Situational scepticism can be presented by audit experience from previous years (Client-Specific Experience). The study uses an experiment $2 \times 3$ factorial design between subjects with divides personal scepticism into high and low, and case of situational scepticism about audit experience from previous years into positive, neutral and negative. The subject of experiment are 84 undergraduate accounting department students who have learned the course of auditing. ANOVA is applied as a tool to attempt the hypotheses. The result reveals that audit judgement made by auditor is influenced by their experience with client from previous years.
\end{abstract}

Keyword: Professional Scepticism, Personal Scepticism, Situational Scepticism, Audit Judgements.

\begin{abstract}
Abstrak: Penelitian ini bertujuan untuk menguji pengaruh skeptisisme personal dan situasional terhadap penilaian audit. Skeptisisme situasional dapat disajikan oleh pengalaman audit dari tahun-tahun sebelumnya (Pengalaman Khusus Klien). Penelitian ini menggunakan desain eksperimen faktorial $2 \times 3$ antara subjek dengan membagi skeptisisme pribadi menjadi tinggi dan rendah, dan kasus skeptisisme situasional tentang pengalaman audit dari tahun-tahun sebelumnya menjadi positif, netral dan negatif. Subjek eksperimen adalah 84 mahasiswa jurusan akuntansi sarjana yang telah mempelajari jalannya auditing. ANOVA diterapkan sebagai alat untuk mencoba hipotesis. Hasilnya mengungkapkan bahwa penilaian audit yang dibuat oleh auditor dipengaruhi oleh pengalaman mereka dengan klien dari tahun-tahun sebelumnya.
\end{abstract}

Kata Kunci: Skeptisisme Profesional, Skeptisisme Pribadi, Skeptisisme Situasional, Keputusan Audit.

\section{PENDAHULUAN}

Kompleksitas transaksi bisnis dan standar akuntansi yang terus meningkat menyebabkan semakin berkembangnya kebutuhan laporan keuangan untuk pemenuhan informasi baik untuk pihak internal maupun eksternal. Karenanya, adanya audit laporan keuangan memiliki peran penting untuk mengurangi berbagai risiko informasi yang terdapat pada laporan keuangan (Francis, 2011). Risiko informasi yang dimaksud adalah laporan keuangan tidak benar dalam pemberian opini, informasi kurang lengkap dan terjadinya bias dalam laporan keuangan itu sendiri. Risiko informasi ini muncul disebabkan adanya konflik kepentingan antara pihak internal dan eksternal, sehingga diperlukannya auditor untuk mengaudit laporan keuangan (Suryanto et al. 2017). 
Tujuan audit atas laporan keuangan adalah untuk memberikan informasi yang benar kepada pembaca laporan keuangan serta tidak terdapat kesenjangan harapan antara pembaca dan pemilik (Brierley dan Gwilliam, 2017). Namun demikian, akhir-akhir ini banyak kasus yang terjadi disebabkan ketidakmampuan auditor dalam mengurangi risiko informasi pada laporan keuangan tersebut, seperti kasus Ernst dan Young ShinNihon LLC yang merupakan auditor independen PT. Thosiba tidak dapat mengungkap penggelembungan laba senilai US \$1.22 miliar sejak tahun 2008 (Gloria, 2015).

Ketidakmampuan auditor dalam mengurangi risiko informasi yang ada salah satunya disebabkan kegagalan auditor dalam menerapkan sikap skeptisisme (Chen et al., 2012). Menurut Fransiska (2015) memiliki sikap profesional yang tinggi seharusnya menyebabkan auditor akan lebih teliti dan cermat dalam melakukan penugasan audit. Salah satu sikap profesional yang harus ada dalam diri auditor adalah sikap skeptisisme profesional, dengan menerapkan sikap skeptisisme profesional pada setiap auditor diharapkan dapat mengurangi risiko informasi yang ada.

Kegagalan penerapan skeptisisme profesional yang tidak tepat oleh auditor merupakan salah satu penyebab terjadinya defisiensi dan kegagalan audit yang berdampak pada memburuknya reputasi jasa audit dan timbulnya krisis kredibilitas (SamsonovaTaddei dan Humphrey, 2015). Novianti (2008) menguatkan bahwa salah satu penyebab besar kegagalan auditor dalam mendeteksi kecurangan adalah rendahnya tingkat skeptisisme profesional audit.

Dalam melaksanakan seluruh kegiatan audit dari penerimaan penugasan, perencanaan, pekerjaan lapangan hingga pelaporan, seorang auditor membutuhkan ekspektasi awal untuk melakukan pengungkapkan kecurangan maupun kesalahan yang terjadi guna mempertahankan sikap skeptisisme profesional. Ekspektasi awal dalam keputusan audit digunakan untuk menentukan kemungkinan salah saji material dan faktor yang mempengaruhi salah saji material. Fransiska (2015) mengatakan ekspektasi awal audit dilihat berdasarkan skeptisisme profesional auditor diduga memiliki potensi salah saji material berupa kecurangan (fraud) atau kekeliruan (error).

Standar Akuntansi seksi 311 paragraf 7 menyatakan, dalam mengaudit laporan keuangan seorang auditor harus mempertimbangkan hal utama yaitu tentang salah saji material yang dihasilkan oleh kecurangan (fraud) (IAPI, 2011). Ekspektasi awal kecurangan atau kekeliruan dalam keputusan audit yang dilakukan auditor dapat mempengaruhi prosedur audit dan pemberian opini. Dalam pekerjaan audit, seorang auditor harus dapat mengembangkan ekspektasi awal berdasarkan pengalaman tahun sebelumnya dengan klien. Walaupun pada tahun sebelumnya auditor mendapatkan pengalaman dengan klien positif tetapi sikap skeptisisme profesional tetap harus dipertahankan (Yendrawati dan Ragil, 2017).

Penelitian Quadackers et al. (2014) menemukan bahwa skeptisisme profesional dipengaruhi oleh fraud risk assessment (penaksiran risiko kecurangan) yang diberikan oleh atasan auditor (auditor in charge) sebagai pedoman dalam melakukan audit di lapangan. Carpenter dan Reimers (2013) juga mengungkapkan bahwa auditor yang berada pada level rendah (auditor junior) cenderung lebih skeptis dibandingkan dengan auditor yang berada pada level tinggi (auditor senior). Penelitian ini senada yang dilakukan oleh Noviyanti (2008). Hal ini mengindikasikan bahwa semakin berpengalaman seorang auditor maka semakin rendah sikap skeptisisme yang dimiliki menyebabkan kesalahan penaksiran risiko kecurangan dan kekeliruan semakin besar. 
Berdasarkan latar belakang yang dikemukakan di atas, maka peneliti mencoba untuk menguji kembali pengaruh skeptisisme profesional sebagai karakter personal terhadap keputusan audit dengan berfokus pada pengujian empiris bagaimana pengaruh skeptisisme profesional dari pengalaman mengaudit sebelumnya atau Client Spesific Experience (CSE) terhadap keputusan audit, serta bagaimana pengaruh perbandingan skeptisisme personal dengan skeptisisme situasional berdasarkan pengalaman mengaudit sebelumnya atau Client Spesific Experience (CSE).

Berbeda dengan penelitian-penelitian sebelumnya tentang skeptisisme auditor yang kebanyakan dilakukan dengan pendekatan survey, seperti penelitian Adrian (2013), Anggriawan (2014), Oktarini dan Ramantha (2016) Astuti dan Saputra (2016), dan Suryanto et al. (2017), penelitian ini dilakukan dengan menggunakan desain eksperimen yang masih sangat jarang dilakukan, setidaknya untuk isu ini pada konteks Indonesia. Pendekatan eksperimen penting dilakukan untuk mengangkat isu skeptisisme auditor agar dapat ditemukan validitas internal yang lebih kuat dibandingkan dengan pendekatan survey yang kuat dari segi validitas eksternal (Nahartyo, 2012). Dari sini maka hasil penelitian ini akan memberikan khasanah baru dalam referensi penelitian terkait skiptisisme auditor dalam kaitannya dengan audit jdugment.

\section{KAJIAN TEORI}

Teori Identitas Sosial. Menurut teori identitas sosial yang diusung Tajfel dan Turner (1985) menyatakan bahwa orang cenderung untuk mengklasifikasikan diri mereka sendiri dan orang lain ke dalam berbagai kategori sosial (Hogg, 2016). Ashfort dan Mael (1989) berpendapat bahwa individu mendefinisikan dirinya sebagai bagian dari kelompok tertentu yang dianggap penting oleh individu. Menurut Jhon Trunner's dan Michael Hagg (1992, 1996) yang manusia mendefinisikan dirinya berdasarkan kelompok (Ginintasasi, 2016). Kategorisasi pribadi berperan penting dalam berpikir serta melakukan interaksi hubungan sosial. Penerapan teori identitas sosial terus meningkat seiring dengan setiap individu bersosial dengan kelompok.

Seorang individu memiliki kecenderungan untuk berkelompok dengan individu lain yang dirasa dapat menarik perhatian individu sendiri (Ashfort dan Mael, 1989). Ashfort dan Mael (1989) berpendapat jika identitas sosial disebabkan oleh persepsi kesatuan individu dalam suatu kelompok, yang melibatkan pengalaman dari kegagalan maupun keberhasilan yang telah dicapai. Berdasarkan teori tersebut setiap individu akan meningkatkan kemampuan diri baik dalam identitas pribadi maupun identitas sosial.

Dari berbagai paparan di atas, teori identitas sosial menyimpulkan bahwa individu yang bekerja di dalam perusahaan memiliki kedekatan langsung dengan klien yang mana merupakan bagian penting dalam sebuah pekerjaan. Seorang auditor akan melakukan pekerjaan audit dengan klien untuk periode waktu yang lama sehingga akan memunculkan identifikasi klien.

Dalam praktik audit, auditor harus memahami bisnis klien, sistem informasi akuntansi yang ada di dalam perusahaan klien dan mengetahui karyawan inti di perusahaan klien, sehingga seorang audior akan melakukan identifikasi terhadap klien (Harindahyani, 2017). Dalam kaitannya dengan penelitian ini, adanya interaksi auditor dalam kurun waktu yang cukup lama dengan klien bisa saja mempengaruhi keputusan yang diambil auditor. Hal ini sebagaimana yang dijelaskan oleh beberapa para ahli di atas bahwa interaksi sosial dalam proses audit menjadikan auditor merasa memiliki hubungan 
emosional kelompok dengan kliennya, dan selanjutnya akan memperngaruhi sikap skeptisisme dari auditor (Suryanto et al., 2017).

Skeptisisme Profesional. Skeptisisme profesional merupakan konsep yang sering dibahas dalam standar profesional audit. Dalam SAS no. 1 sikap skeptisisme profesional didefinisikan sebagai sikap yang mencakup pikiran pertanyaan dan penilaian kritis dalam melakukan bukti audit (Hurtt et al., 2013). Auditor menggunakan pengetahuan, keterampilan dan kemampuan dalam mengevaluasi bukti. Auditor tidak mengasumsikan bahwa manajemen tidak jujur atau diragukan kejujurannya (Carpenter dan Reimers, 2013), melainkan auditor berpandangan netral pada manajemen. Dengan kata lain, auditor mengumpulkan dan mengevaluasi bukti tetapi tidak menganggap bias.

Dalam mendefinisikan sikap skeptisisme profesional dalam berbagai literatur belum konsisten. Beberapa literatur berpendapat sikap skeptisisme profesional merupakan sikap netral. Hurtt et al. (2013) mendefinisikan sikap skeptisisme profesional dalam berbagai karakteristik skeptis seperti questioning mind, suspension of judgment dan search for knowledge. Beberapa literatur lainnya berpendapat bahwa sikap skeptisisme profesional merupakan dugaan keraguan. Sebagai konsekuensinya, dalam berpendapat auditor membutuhkan pengumpulan bukti yang lebih banyak sebelum memberikan opini (Quadackers et al., 2014).

Sementara, Hurtt et al. (2013) menjelaskan bahwa skeptisisme profesional adalah karakteristik individu multi-dimensi. Menurut Hurtt et al. (2013) karakteristik individu skeptisisme profesional di bagi menjadi dua yaitu sifat personal yang dipengaruhi oleh diri sendiri dan sikap situasional yang dipengaruhi faktor tertentu. Popova (2013) menerangkan sikap skeptisisme situasional didasarkan pada pengalaman mengaudit sebelumnya (Client Spesific Experience) antara klien dan auditor, serta menjelaskan terdapat beberapa tipe CSE (Client Spesific Experience) yaitu CSE negatif, CSE positif dan netral.

Dalam kasus kegagalan audit, salah satu faktor yang dinilai mempengaruhi adalah rendahnya sikap skeptisisme profesional, sehingga menyebabkan tidak pekanya auditor terhadap kecurangan yang ada, baik yang tidaksengaja maupun yang disengaja (Chen et al., 2012). Auditor yang menerapkan sikap skeptisisme profesional akan kritis dalam melakukan penugasan audit, memperhitungkan resiko yang ada dan mengumpulkan bukti audit. Sementara itu, faktor situasional juga merupakan salah satu faktor penting dalam skeptisisme profesional. Sehingga peneliti menghubungkan skeptisisme profesional personal dan situasional terhadap keputusan audit. Ini memungkinkan jika memiliki skeptisisme profesional personal tinggi dan skeptisisme profesional situasional tinggi pula akan memberikan pengaruh terhadap ekpektasi awal auditor (Popova, 2013).

Keputusan Audit dan Ekspektasi Awal Kecurangan dan Kekeliruan. Kecurangan dalam laporan keuangan sangat berbeda dengan kekeliruan (Herawati, 2015). Suryanto et al. (2017) menyatakan kecurangan dalam laporan keuangan sulit untuk di deteksi sebab biasanya disembunyikan. Hal-hal yang disembunyikan biasanya berupa catatan akuntansi atau dokumen bukti transaksi. Ketika auditor meminta bukti transaksi maka akan mendapatkan transaksi palsu. Dalam SAS no. 99 menjelaskan kecurangan merupakan tindakan yang disengaja menyebakan salah saji pada laporan keuangan (AICPA, 2003). Fransiska (2015) mengatakan kecurangan di kategorikan menjadi dua jenis yaitu misappropriation of assets dan fraudulent financial reporting. 
Sementara itu kekeliruan merupakan kesalahan dalam mendiskripskan dan menyimpulkan perhitungan saat pengaplikasi standar akuntansi (Fransiska, 2015; Yusrianti, 2015; Fuad, 2015). Keputusan audit dalam SAS no. 99 menjelaskan auditor harus mengatasi kecenderungan terlalu percaya kepada klien dengan pendekatan audit yang disertai sikap skeptis dan pikiran yang mempertanyakan (Waluyo, 2017) sejak ketika menyusun perencanaan audit. Apabila dari aspek perencanaan auditor mengabaikan skeptisisme ini, maka dikhawatirkan akan mepengaruhi sikap auditor dalam membuat keputusan audit yang berdampak pada hasil akhir audit.

Dampak dari Skeptisisme Profesional sebagai Karakter Personal terhadap Keputusan Audit. Semua orang memiliki latar belakang yang berbeda dalam mempercayai suatu hal. Noviyanti (2008) menyatakan keyakinan yang dimiliki setiap orang dipengaruhi oleh beberapa faktor yaitu kepribadian dan karakter individu masingmasing. Pada dasarnya, setiap karakter personal individu dapat menentukan apakah suatu hal dapat dipercaya atau tidak (Popova, 2012; Chen et al. 2012; Glover dan Prawitt, 2014).

Skeptisisme profesional salah satunya dibentuk oleh karakter personal auditor. Skeptisisme profesional memiliki tingkat yang berbeda antar individu. Quadackers et al. (2014) berpendapat auditor yang memiliki tingkat skeptisisme personal yang tinggi maka cenderung menyimpulkan salah saji karena kecurangan. Karakateristik individu seorang auditor mempengaruhi tingkat skeptisisme profesional juga didukung oleh Suryanto et al. (2016). Mereka menjelaskan bahwa auditor yang berasal dari suku jawa memiliki karakteristik halus dan cenderung menghindari konfilik dengan klien. Konsekuensinya, sikap skeptisisme termitigasi oleh karakteristik dari etnis jawa yang mementingkan keharmonisan. Hal ini dapat menyebabkan auditor yang memiliki sikap skeptisisme profesional akan memilih untuk menjaga keharmonisan ketimbang mencurigai klien. Selanjutnya, sikap skeptisisme profesional ini memberikan pengaruh dalam pengambilan keputusan audit atas salah saji material pada laporan keuangan.

Popova (2013) mengatakan auditor dengan tingkat skeptisisme tinggi akan lebih cenderung memilih kecurangan sebagai ekspektasi awal atas risiko salah saji material dalam laporan keuangan. Auditor yang memiliki tingkat skeptisisme tinggi cenderung tidak mempercayai penjelasan klien sehingga cenderung menyimpulkan salah saji disebabkan karena kecurangan ketimbang kekeliruan. Berdasarkan argumentasi tersebut, maka hipotesis yang dirumuskan adalah sebagai berikut:

$\mathbf{H}_{1}$ : Auditor dengan tingkat skeptisisme personal yang tinggi memilih kecurangan sebagai ekspektasi awal dibandingkan dengan auditor yang memiliki karakter skeptisisme lebih rendah.

Dampak Skeptisisme Profesional dari Pengalaman Mengaudit Sebelumnya atau Client Spesific Experience (CSE) terhadap Keputusan Audit. Selama melaksanakan audit, auditor perlu meningkatkan ekspektasi awal dalam pengambilan keputusan guna menyimpulkan laporan keuangan salah saji atau tidak. Auditor dapat mengambangkan ekspektasi awal melalui keyakinan diri sendiri atau dengan penjelasan klien. SAS No. 99 mengatur tentang audit berkelanjutan, auditor seharusnya mampu mempertahankan sikap skeptisisme profesional untuk melaksanakan kegiatan audit dengan mengabaikan pengalaman mengaudit sebelumnya dengan klien yang sama atau memiliki keyakinan awal terhadap kejujuran dan integritas klien (AICPA, 2003).

Popova (2013) menjelaskan ketika auditor memiliki pengalaman mengaudit sebelumnya atau Client Spesific Experience (CSE) negatif maka auditor dapat 
beranggapan bahwa penjelasan yang diberikan klien kurang dapat dipercaya sedangkan menurut Popova (2013) ketika auditor memiliki pengalaman mengaudit sebelumnya atau Client Spesific Experiences (CSE) positif penjelasan klien yang diberikan dapat dipercaya. Hasil ini tidak jauh berbeda dengan penelitian Cahan dan Sun (2015) yang menemukan auditor yang diberikan penaksiran tingkat risiko kecurangan rendah akan kurang skeptis dibandingkan dengan auditor yang diberikan tingkat risiko kecurangan tinggi (Nikolova et al., 2015).

Hasil ini mendukung penelitian Popova (2013) yang mengemukakan bahwa pengalaman mengaudit klien pada tahun sebelumnya berpengaruh dalam menentukan ekspektasi awal audit terhadap risiko salah saji material. Auditor yang memiliki pengalaman mengaudit sebelumnya atau Client Spesific Experiences (CSE) negatif beranggapan bahwa klien kurang dapat dipercaya dan memilih ekspektasi awal sebagai kecurangan. Auditor yang memiliki pengalaman mengaudit sebelumnya atau Client Spesific Experiences (CSE) positif beranggapan bahwa klien dapat dipercaya dan memilih ekspektasi awal sebagai ketidak sengajaan. Berdasarkan argumentasi tersebut, maka hipotesis yang dirumuskan adalah sebagai berikut:

H2: Auditor yang mendapatkan CSE negatif memilih kecurangan sebagai ekspektasi awal mereka dibandingkan dengan auditor yang memperoleh CSE positif.

\section{Perbandingan Skeptisisme Personal dengan Skeptisisme Situasional dari} Pengalaman Mengaudit Sebelumnya atau Client Spesific Experience (CSE). Auditor yang memiliki tingkat skeptisisme yang rendah tergiring luntuk percaya kepada klien disebabkan oleh pandangan bahwa setiap orang pada umumnya dapat dipercaya (Waluyo, 2017). Noviyanti (2008) mengatakan kepercayaan dalam hubungan auditor dengan klien dapat mempengaruhi sikap skeptisisme profesional. Oleh sebab itu, jika auditor kurang skeptis maka auditor memiliki keyakinan yang tinggi terhadap klien. mengatakan auditor dengan tingkat skeptisisme tinggi akan lebih teliti dalam melaksanakan kegiatan audit dibandingkan dengan auditor yang memiliki tingkat skeptisisme rendah (Suryanto et al., 2017).

Noviyanti (2008) berpendapat bahwa tingkat kepercayaan auditor yang rendah terhadap klien cenderung meningkatkan sikap skeptsisme profesional, dan sebaliknya tingkat kepercayaan auditor yang tinggi terhadap klien akan menurunkan sikap skeptisisme profesional. Hasil ini mendukung penelitian Popova (2013) yang mengatakan auditor dengan tingkat skeptisisme yang lebih rendah cenderung lebih mempercayai klien sehingga ketika auditor memperoleh pengalaman mengaudit sebelumnya atau Client Spesific Experiences (CSE) positif, auditor cenderung menentukan ekspektasi awal sebagai kekeliruan atas resiko salah saji laporan keuangan. Sebaliknya, ketika auditor memperoleh pengalaman mengaudit sebelumnya atau Client Spesific Experiences (CSE) negatif, maka akan ada ketimpangan kepercayaan auditor dengan pengalaman negatif yang dialami auditor yang menyebabkan auditor cenderung memberikan ekspektasi awal berupa kecurangan atas resiko salah saji laporan keuangan.

Maka dari itu, auditor yang memiliki pengalaman mengaudit sebelumnya atau Client Spesific Experiences (CSE) negatif akan lebih memilih kecurangan sebagi ekspektasi awal walaupun memiliki sikap skeptisisme personal yang lebih rendah dibanding auditor yang memiliki pengalaman mengaudit sebelumnya atau Client Spesific Experiences (CSE) positif lebih memilih kekeliruan walaupun memiliki sikap skeptisisme personal yang 
tinggi. Berdasarkan argumentasi tersebut, maka hipotesis yang dirumuskan adalah sebagai berikut:

H3: Perbedaan paling signifikan yang dihasilkan atas CSE positif dan negatif yang diperoleh auditor pada tahun sebelumnya akan lebih terlihat pada auditor yang memiliki tingkat skeptisisme personal yang lebih rendah.

Model Penelitian. Dari hipotesis yang dibangun peneliti, maka dapat disusun model penelitian sebagaimana yang disajikan pada Gambar 1.

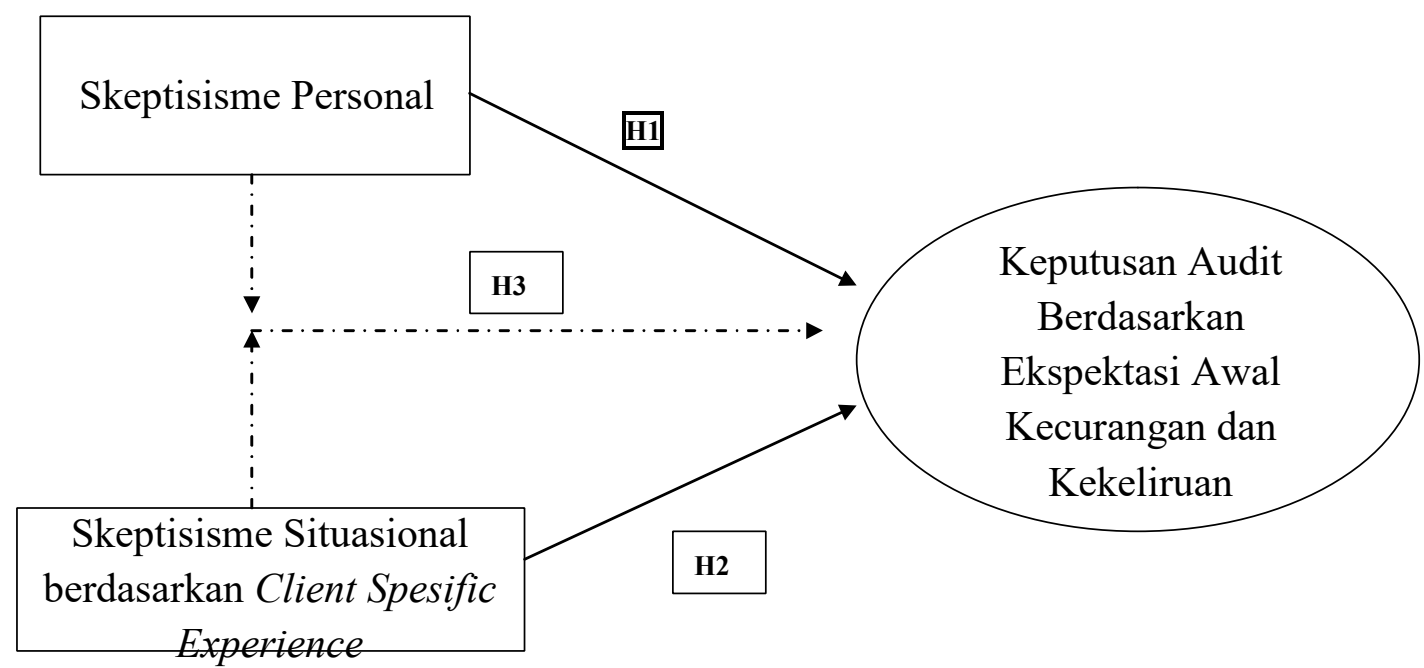

Gambar 1. Model Penelitian

\section{METODE}

Desain Penelitian. Desain penelitian ini menggunakan desain eksperimen $2 \times 3$ faktorial antarsubjek (between subject) dengan dua variabel independen. Variabel independen pertama adalah skeptisisme personal yaitu skeptisisme tinggi dan rendah. Sedangkan variabel independen kedua adalah skeptisisme situasional yaitu pengalaman mengaudit sebelumnya atau Client Spesific Experience (CSE) positif, negatif dan netral. Desain ini digambarkan dalam bentuk matriks sebagaimana disajikan pada Tabel 1. Pada Gamber 1 disajikan eksperimen dimana perlakuan kepada subjek eksperimen dibagi menjadi 6 (enam) SEL.

Tabel 1. Desain Eksperimen

\begin{tabular}{lcccc}
\hline \multirow{2}{*}{ Faktor dan Level } & \multicolumn{3}{c}{ Skeptisisme Situasional (B) } \\
\cline { 3 - 5 } & & CSE Positif (B1) & CSE Negatif(B2) & CSE Netral (B3) \\
\hline Skeptisisme & Tinggi (A1) & SEL 1 (A1B1) & SEL 2 (A1B2 & SEL 3 (A1B3) \\
Personal (A) & Rendah (A2) & SEL 4 (A2B1) & SEL 5 (A2B2) & SEL 6 (A2B3) \\
\hline
\end{tabular}

Subjek Eksperimen. Subjek dalam penelitian ini adalah mahasiswa S1 akuntansi yang telah menempuh mata kuliah dan praktikum audit di Universitas Muhammadiyah Yogyakarta. Penentuan kriteria tersebut agar subjek sudah mengerti praktik audit laporan keuangan secara umum, sehingga ketika mendapatkan manipulasi subjek dapat memahami apa yang harus dilakukan. Pemilihan subjek dari mahasiswa ini dikarenakan subjek belum memiliki pengalaman audit di lapangan sehingga tidak dipengaruhi faktor lain seperti 
pengalaman mengaudit dan waktu lama mengaudit. Subjek eksperimen yang terkumpul didistribusikan ke beberapa manipulasi (CSE positif, CSE negatif dan netral) secara acak.

Prosedur Eksperimen. Sebelum melakukan eksperimen, peneliti melakukan pilot-test terlebih dahulu terhadap 15 orang mahasiswa. Pilot- test ini berguna untuk mengevaluasi, memberikan masukan terhadap instrumen yang akan digunakan dalam eksperimen. Penelitian eksperimen dilakukan dalam waktu 20-30 menit, dan terbagi menjadi dua tahap. Tahap pertama, partisipan dikelompokkan berdasarkan tingkat skeptisisme personal yang diukur menggunakan skala Hurtt (2010). Pengukuran ini sama dengan yang dilakukan Popova (2013). Pada tahap pertama ini diberikan waktu 20 menit untuk menjawab pertanyaan. Setelah itu diberi jarak waktu selama satu minggu lalu masuk tahap kedua. Pada waktu satu minggu tersebut peneliti mengolah data hasil uji tingkat skeptisime dari mahasiswa ke dalam kelompok skiptisisme rendah dan tinggi. Dalam waktu satu minggu itu pula, peneliti mendesain eksperimen untuk tahap dua.

Pada tahap kedua, partisipan diberikan kasus yang berisi manipulasi dimana subjek seolah-olah telah memiliki pengalaman mengaudit sebelumnya atau Client Spesific Experience (CSE). Manipulasi ini terbagi menjadi 3 jenis yaitu CSE positif, CSE negative dan netral. Pembagian kepada partisipan dilakukan secara acak. Dalam tahap kedua ini diberikan waktu 30 menit untuk memecahkan persoalan yang diberikan. Penelitian ini dilakukan pada awal jam kuliah. Setelah melakukan eksperimen, data yang ada diolah dengan teknik ANOVA.

Operasional Variabel dan Pengukurannya. Skeptisisme personal diukur menggunakan Hurtt (2010). Skala tersebut memiliki 30 pertanyaan dengan setiap 1 pertanyaan mewakili salah satu dari 6 karakteristik skeptisisme profesional dari Hurtt (2010). Instrumen tersebut menggunakan skala likert 6 poin. Penelitian ini tidak memasukkan skala pertengahan agar mencegah responden memilih skor rata-rata (Permana, 2015). Pertanyaan pada butir $1,10,11,16,17,19,25$ dan 26 dihitung penilaian secara terbalik. Penilaian mengakumulasi jawaban partisipan, dengan skor 0 sampai 180 dimana skor di atas nilai tengah (median) menunjukkan tingkat skeptisisme yang tinggi sedangkan skor di bawah nilai tengah menunjukkan tingkat skeptisisme yang rendah.

Skeptisisme situasional diukur dengan instrumen dari Popova (2013) dengan model scenario kasus audit pada beberapa perubahan. Instrumen terdiri dari deskripsi yang menggambarkan pengalaman mengaudit klien pada tahun sebelumnya, deskripsi yang menggambarkan pengalaman mengaudit klien pada tahun sekarang dan satu pertanyaan sebagai manipulation check yang disajikan secara singkat dan jelas. Deskripsi tentang pengalaman mengaudit di tahun sebelumnya dibagi menjadi 3 yaitu CSE positif, CSE negatif dan netral. Sedangkan deskripsi tentang pengalaman mengaudit klien pada tahun sekarang hanya satu deskripsi yang sama.

Setelah membaca kedua situasi yang berbeda maka partisipan akan menjawab pertanyaan pertama sebagai manipulation check untuk mengetahui apakah terjadi perubahan pemikiran dalam diri partisipan atas deskripsi yang diberikan. Partisipan diminta untuk menentukan apakah klien dapat dipercaya atau tidak dengan menggunakan skala interval yang diberikan dari 1 hingga 10. Dengan poin 1 menunjukan bahwa klien "sangat tidak dipercaya" dan poin 10 menunjukan klien "sangat dipercaya".

Keputusan audit yang merupakan ekspektasi awal berupa kecurangan atau kekeliruan merupan variabel dependen dalam penelitian ini. Keputusan audit diukur dengan satu pertanyaan terkait deskripsi pengalaman audit sebelumnya dan pengalaman 
audit tahun berjalan. Partisipan menentukan ekspektasi awal audit dengan melihat apakah resiko salah saji material yang ditemukan disebabkan oleh kecurangan atau kekeliruan semata. Partisipan diminta menjawab dengan menggunakan skala interval dari poin -10 hingga 10. Poin -10 menunjukkan kecurangan, poin 0 menunjukkan netral dan poin 10 menunjukan kekeliruan.

Pengujian Hipotesis. Pengujian hipotesis pada eksperimen dilakukan dengan teknik Analysis of Variance (ANOVA), yaitu model statistik yang digunakan untuk menganalisis perbedaan rata-rata antara kelompok dan prosedur terkait (seperti "variasi" antara kelompok) (Nazaruddin dan Basuki, 2015). Hipotesis dinyatakan terdukung jika hipotesis memperoleh nilai signifikansi (sig.) kurang dari 0,05.

\section{HASIL DAN PEMBAHASAN}

Demografi Subjek. Penelitian ini dilakukan di Universitas Muhammadiyah Yogyakarta. Demografi Subjek disajikan pada Tabel 2. Dari Tabel 2 dapat disimak bahwa jumlah keseluruhan subjek adalah 84. Sebenarnya terdapat 91 subjek yang mengikuti eksperimen dan menyerahkan instrumen penelitian. Namun, terdapat 7 (tujuh) kuisioner yang tidak diisi secara lengkap sehingga tidak dapat diolah.

Tabel 2. Demografi Subjek

\begin{tabular}{|c|l|r|}
\hline Keterangan & \multicolumn{1}{|c|}{ Deskripsi } & \multicolumn{1}{c|}{ Jumlah } \\
\hline \multirow{3}{*}{ Jenis Kelamin } & Jumlah Responden & 84 \\
\cline { 2 - 3 } & Laki-Laki & 23 \\
\cline { 2 - 3 } & Perempuan & 61 \\
\hline \multirow{3}{*}{ Usia } & Jumlah Responden & 84 \\
\cline { 2 - 3 } & $<20$ tahun & 12 \\
\cline { 2 - 3 } & $21-22$ tahun & 71 \\
Menempuh Mata & Jumlah Responden & 84 \\
\cline { 2 - 3 } Kuliah Audit & Sudah & 84 \\
\cline { 2 - 3 } & Belum & 0 \\
\hline
\end{tabular}

Cek Manipulasi. Pengecekan manipulasi dilakukan untuk menguji apakah pemberian deskripsi kasus telah direspon oleh subjek dan keadaan yang diinginkan sesuai dengan peneliti harapkan (Nahartyo dan Utami, 2016). Untuk itu, subjek yang memberikan nilai lebih dari 5 menunjukkan bahwa subjek percaya dengan klien dan yang memberikan nilai dibawah 5 menunjukkan bahwa subjek tidak percaya dengan klien.

Tabel 3. Hasil Cek Manipulasi

\begin{tabular}{|l|r|r|r|r|r|}
\hline & $\mathrm{N}$ & Mean & $\begin{array}{c}\text { Std. } \\
\text { Deviation }\end{array}$ & $\mathrm{F}$ & Sig. \\
\hline Netral & 27 & 5.519 & .3793 & & \\
Positif & 28 & 5.625 & .3758 & \multirow{2}{*}{105.269} & .000 \\
Negatif & 29 & 4.276 & .4137 & & \\
Total & 84 & 5.125 & .7317 & & \\
\hline
\end{tabular}


Pada Tabel 3 disajikan hasil pengecekan manipulasi. Dari hasil pengecekan manipulasi iniditemukan bahwa subjek yang mendapatkan pengalaman mengaudit sebelumnya (CSE) negatif cenderung tidak mempercayai klien hal ini dapat dilihat pada mean yaitu 4,276 (deviasi standar 0,4137). Berbeda dengan subjek yang mendapatkan pengalaman mengaudit sebelumnya (CSE) positif dengan mean 5,625 (deviasi standar 0,3758) dan netral dengan mean 5,519 (deviasi standar 0,3793), mereka cenderung mempercayai klien. Perbedaan tersebut signifikan pada $\alpha=0,000$ dengan $\mathrm{f}=105,269$. Dari data statistik ini, maka dapat disimpulkan bahwa pengalaman mengaudit sebelumnya (CSE) berpengaruh signifikan terhadap tingkat kepercayaan klien. Hasil ini mengindikasikan bahwa pengecekan manipulasi berhasil dilaksanakan.

Hasil Uji Hipotesis. Sebelum dilakukan uji ANOVA, terlebih dahulu dilakukan pengujian homogenitas data untuk memenuhi asumsi pengujian ANOVA. Berdasarkan pada hasil yang diperoleh dalam test of homogeneity of variances, dimana dihasilkan signifikannya adalah 0,391 yang berarti lebih besar dari $\alpha$ 0,05. Dengan demikian dapat disimpulkan bahwa asumsi setiap kelompok berasal dari populasi dan variansi yang sama diterima. Hasil ini mengindikasikan bahwa tingkat kepercayaan terhadap klien berdasarkan pengalaman mengaudit sebelumnya memiliki varian populasi yang sama dan asumsi ANOVA terpenuhi.

Tabel 4. Deskriptif Statistik Skeptisisme Personal dan Situasional (Rata-rata, Standart Deviasi dan Jumlah Mahasiswa)

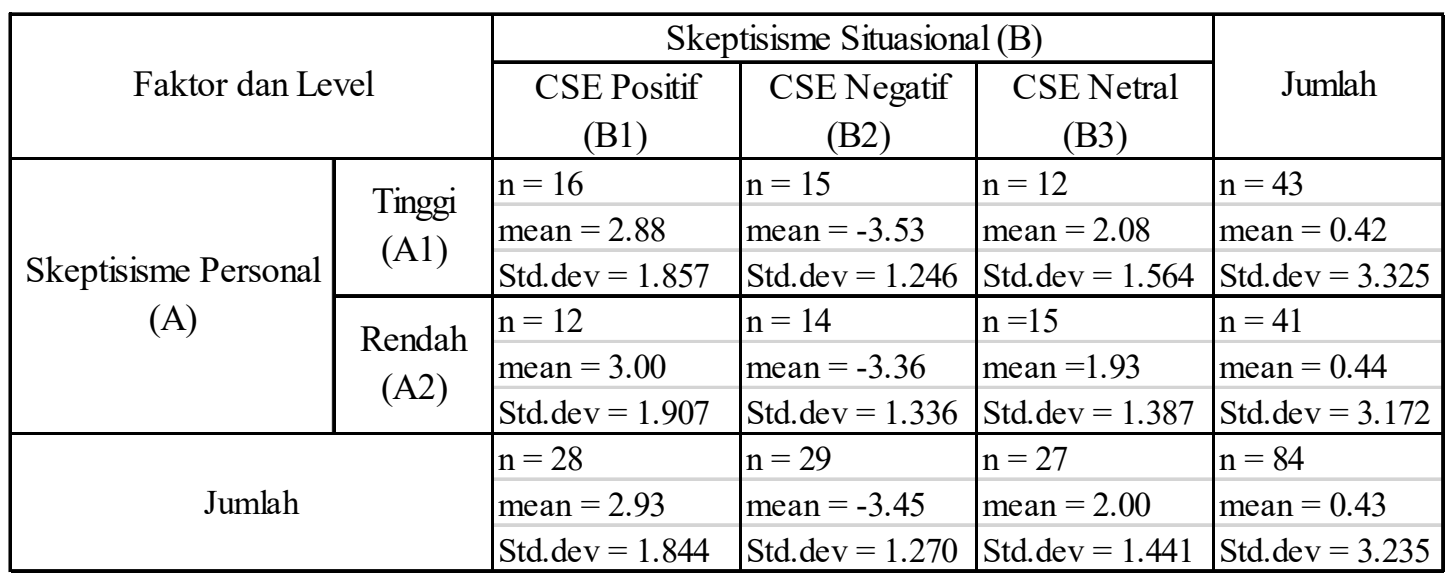

Tabel 4 menunjukkan rata-rata skeptisisme personal (tinggi-rendah) dan skeptisisme situasional (CSE positif, negatif dan netral). Dari Tabel 4 diketahui nilai mean yang dilihat dari skeptisisme personal tidak memiliki perbedaan yang mencolok antara yang skeptisismenya tinggi dan rendah. Selanjutnya pada Tabel 5 disajikan hasil pengujian hipotesis pertama dengan menggunakan two way ANOVA. Berdasarkan hasil analisis ANOVA, tingkat skeptisisme tinggi pada subjek dengan nilai mean 0,475 cenderung memilih ketidaksengajaan dari pada kecurangan sebagai ekspektasi awal dan begitu pula tingkat skeptisisme rendah pada subjek dengan nilai mean 0,525 . Perilaku subjek memilih ketidaksengajaan sebagai ekspektasi awal ini mengindikasikan bahwa tingkat skeptisisme tidak berpengaruh terhadap ekspektasi awal audit. Hasil ini didukung dengan pengujian skeptisisme, berdasarkan pengujian angka sig. 0,884 $>0,05$. Dari hasil ini maka dapat 
disimpulkan bahwa tingkat skeptisisme subjek tidak berpengaruh signifikan terhadap ekspektasi awal audit berupa kecurangan atau kekeliruan, H1 tidak terdukung.

Selanjutnya, pengujian $\mathrm{H}_{2}$ juga dapat disimak pada Tabel 5. Berdasarkan hasil uji ANOVA yang diperoleh, kasus pengalaman mengaudit sebelumnya (CSE) netral yang diberikan pada subjek memiliki mean 2,00 dan kasus pengalaman mengaudit sebelumnya (CSE) positif yang diberikan pada subjek memiliki mean 2,93.

Tabel 5. Hasil Pengujian ANOVA Hipotesis 1 dan 2

Skeptisisme Personal terhadap Keputusan Audit dan Skeptisisme Situasional terhadap Keputusan Audit

\begin{tabular}{ccccc}
\hline \multicolumn{2}{c}{ Skeptisisme } & Mean & Error & Sig. \\
\hline \multirow{2}{*}{ Personal } & Tinggi & 0,475 & 0,240 & \multirow{2}{*}{ ( 2884} \\
& Rendah & 0,525 & 0,245 & \\
Situasional & Netral & 2,008 & 0,303 & \multirow{2}{*}{0,00} \\
& Positif & 2,937 & 0,298 & \\
& Negatif & $-3,445$ & 0,290 & \\
\hline
\end{tabular}

Hal ini mengindikasikan bahwa subjek dengan kasus CSE netral dan positif cenderung beranggapan bahwa ekspektasi awal atas salah saji material berupa ketidaksengajaan. Ini berbeda dengan kasus pengalaman mengaudit sebelumnya (CSE) negatif yang diberikan pada subjek memiliki mean -3,44. Ini mengindikasikan bahwa subjek cenderung beranggapan bahwa ekspektasi awal atas salah saji materil berupa kecurangan. Hasil ini didukung angka sig. 0,000 $(<0,05)$. Dengan demikian dapat disimpulkan bahwa pengalaman mengaudit sebelumnya (CSE) yang diperoleh subjek berpengaruh secara signifikan terhadap ekspektasi awal apakah kesalahan karena kecurangan atau kekeliruan. Berdasarkan temuan ini dapat disimpulkan $\mathbf{H}_{2}$ terdukung.

Selanjutnya pada Tabel 6 disajikan hasil pengujian hipotesis ketiga. Berdasarkan hasil uji ANOVA, ditemukan bahwa tingkat skeptisisme tinggi lebih cenderung memilih ekspektasi awal berupa kecurangan. Hal ini dapat dilihat dari hasil mean pengalaman mengaudit sebelumnya (CSE) baik yang mendapat positif (mean=0,58), netral $($ mean $=0,44)$ dan negatif (mean $=-0,40)$. Hasil ini menunjukkan subjek tidak terpengaruh oleh pengalaman mengaudit sebelumnya (CSE) baik positif, netral ataupun negatif. Peneliti menyimpulkan tidak ada perbedaan signifikan ketika subjek memiliki tingkat skeptisisme tinggi $(F=1,459$ dan sig. $=0,245)$.

Tabel 6. Hasil Pengujian ANOVA Hipotesis 3

Perbandingan Skeptisisme Personal dan Situasional terhadap Keputusan Audit

\begin{tabular}{|c|c|c|c|c|c|}
\hline Tingkat Skeptisisme & CSE & Mean & \begin{tabular}{|c|} 
Std. \\
Deviation
\end{tabular} & $\mathrm{F}$ & Sig. \\
\hline \multirow{3}{*}{ Tinggi } & Positif & 0,58 & 1,825 & \multirow{3}{*}{1,459} & \multirow{3}{*}{0,245} \\
\hline & Netral & 0,44 & 1,311 & & \\
\hline & Negatif & $(0,40)$ & 1,724 & & \\
\hline \multirow{3}{*}{ Rendah } & Positif & 3,00 & 1,907 & \multirow{3}{*}{66,170} & \multirow{3}{*}{0,000} \\
\hline & Netral & 1,93 & 1,387 & & \\
\hline & Negatif & $(3,36)$ & 1,336 & & \\
\hline
\end{tabular}


Berbeda dengan hasil yang diperoleh pada subjek yang memiliki tingkat skeptisisme rendah, mereka cenderung akan dipengaruhi oleh pengalaman mengaudit tahun sebelumnya (CSE) dalam memilih ekspektasi awal. Pada Tabel 6 dapat disimak bahwa subjek yang mendapatkan pengalaman mengaudit tahun sebelumnya (CSE) positif dan netral (mean $=3,00$ dan mean $=1,93$ ) akan memilih kekeliruan sebagai ekspektasi awal salah saji material, sedangkan subjek yang mendapatkan pengalaman mengaudit tahun sebelumnya (CSE) negatif (mean= -3,36) akan memilih kecurangan dari pada kekeliruan sebagai ekspektasi awal salah saji material. Penelitian ini juga menemukan adanya perbedaan yang signifikan pada sikap ekspektasi awal ketika subjek memiliki tingkat skeptisisme rendah $(F=66,170$ dan sig. $=0,000)$. Sehingga, berdasarkan temuan diatas dapat disimpulkan $\mathbf{H}_{3}$ terdukung.

Diskusi. Tingkat skeptisisme yang tidak berpengaruh terhadap judgment pada ekspektasi awal auditor sebagaimana ditunjukkan dari hasil $\mathrm{H} 1$ yang tidak terdukung sejalan dengan hasil penelitian Popova (2013). Alasan yang dapat menjelaskan hal ini yakni sebagaimana yang dikemukakan oleh Suryanto et al. (2017) bahwa skeptisisme auditor bukan berarti auditor harus selau memposisikan klien (auiditee) sebagai pihak yang tidak jujur. Melainkan auditor berpandangan netral pada manajemen, sehingga mereka membutuhkan bukti lebih jauh dan kuat untuk menentukan ekspektasi awal apakah kesalahan yang terjadi nantinya didasarkan pada kecurangan atau ketidaksengajaan. SIkap inilah yang kemungkinan besar dilakukan oleh subjek pada eksperimen ini.

Terdukungnnya $\mathrm{H}_{2}$ penelitian ini menunjukkan auditor yang memiliki pengalaman mengaudit sebelumnya (CSE) dengan klien akan memiliki kecenderungan untuk percaya kepada klien atau tidak. Subjek yang mendapatkan pengalaman mengaudit tahun sebelumnya (CSE) positif dan netral akan memilih kekeliruan sebagai ekspektasi awal mereka. Kondisi ini menyebabkan penentuan kesalahan dalam laporan keuangan disebabkan karena kekeliruan atau ketidak sengajaan klien. Berbeda dengan subjek yang mendapatkan pengalaman mengaudit sebelumnya (CSE) negatif akan memilih kecurangan sebagai ekspektasi awal mereka. Ini menjadikan penentuan kesalahan dalam laporan keuangan disebabkan karena kecurangan klien.

Terdukunganya $\mathrm{H}_{3}$ mengindikasikan bahwa auditor dengan tingkat skeptisisme tinggi tidak akan terpengaruh atau cenderung tetap mempertahankan skeptisisme profesionalnya ketika mendapatkan pengalaman mengaudit sebelumnya (CSE) baik itu positif, netral ataupun negatif dalam memberikan ekspektasi awal mereka terhadap resiko salah saji material yang ditemukan. Berbeda dengan auditor yang memiliki tingkat skeptisisme personal rendah. Mereka akan cenderung memberikan ekspektasi awal berupa kecurangan ataupun kekeliruan ketika mendapatkan pengalaman mengaudit sebelumnya (CSE). Pengalaman mengaudit sebelumnya (CSE) akan menjadi penentu bagi auditor yang memiliki tingkat skeptisisme rendah dalam memberikan ekspektasi awal mereka terhadap resiko salah saji material yang ditemukan.

Penelitian ini mengusulkan tingkat skeptisisme personal dalam pengambilan keputusan audit harus diimbangi dengan informasi tentang klien. Hasil penelitian menunjukkan bahwa tingkat skeptisisme personal dalam pengambilan keputusan ekspektasi awal berupa kecurangan atau kekeliruan tidak dapat didukung oleh penelitian ini. Hasil penelitian ini sama dengan hasil Popova (2013). Popova (2013) menghasilkan kesimpulan bahwa skeptisisme profesional dipengaruhi oleh dua faktor yaitu skeptisisme personal dan situasional. Popova (2013) juga mengatakan pengaruh situasional sangat mempengaruhi auditor dalam membuat keputusan audit sehingga penilaian individu 
(skeptisisme personal) jadi kurang meyakinkan. Temuan ini konsisten dengan Fransiska (2015) yang mengatakan auditor perlu meningkatkan penilaian skeptisisme personal agar mampu mendeteksi kecurangan pada laporan keuangan.

Skeptisisme professional sangat penting pada beberapa tahun terakhir sebab kurangnya sikap skeptisisme professional akan banyak kegagalan audit dalam laporan keuangan yang menyebabkan hilangnya kepercayaan investor. Sehingga sangat penting bagi auditor untuk meningkatkan skeptisisme personal agar kecurangan dalam laporan keuangan dapat dideteksi sedini mungkin.

Hasil penelitian memberikan bukti empiris bahwa pengalaman mengaudit tahun sebelumnya (CSE) berpengaruh pada pengambilan keputusan audit. Pengalaman mengaudit tahun sebelumnya (CSE) dapat mengurangi atau meningkatkan tingkat skeptisisme auditor. Pengalaman tersebut dapat merubah keputusan audit. Popova (2013) mengatakan pengalaman mengaudit tahun sebelumnya (CSE) dapat mempengaruhi auditor yang kurang skeptis, sehingga dapat mempengaruhi keputusan audit. Fransiska (2015) mengatakan auditor seharusnya menjaga tingkat skeptisisme personal mereka tanpa dipengaruhi oleh pengalaman mengaudit, sebab setiap tahun berjalan akan tetap ada resiko kecurangan pada laporan keuangan klien.

Pada penelitian ini disimpulkan bahwa pengalaman mengaudit tahun sebelumnya (CSE) adalah faktor penentu auditor yang memiliki skeptsisme rendah. Auditor akan tidak mempercayai klien dan memberikan ekspektasi awal berupa kecurangan jika auditor memiliki pengalaman mengaudit negatif dengan kliennya. Begitu pula sebaliknya, auditor akan mempercayai klien dan memberikan ekspektasi awal berupa kekeliruan atau ketidak sengajaan jika auditor memiliki pengalaman mengaudit positif pada tahun sebelumnya dengan klien. Hal ini tidak berlaku pada auditor yang memiliki tingkat skeptisisme personal tinggi. Auditor yang memiliki tingkat skeptisisme personal tinggi tidak akan terpengaruh dan cenderung lebih mempertahankan sikap skeptisisme professionalnya. Auditor akan memberikan ekspektasi awal berupa kecurangan dalam mengaudit laporan keuangan.

Hasil penelitian ini dapat menjelaskan bahwa keputusan audit dipengaruhi oleh dua faktor yaitu skeptisisme personal dan situasional. Ketika auditor menentukan ekspektasi awal berupa kecurangan atau kekeliruan, pengalaman mengaudit pada tahun sebelumnya (CSE) dan tingkat skeptisisme akan mempengaruhi bagaimana seorang auditor percaya terhadap klien. Auditor yang memiliki tingkat skeptisisme rendah cenderung akan mempercayai atau tidak mempercayai klien berdasarkan pengalaman mengaudit tahun sebelumnya (CSE).

\section{PENUTUP}

Penelitian ini bertujuan untuk menguji sikap skeptisisme professional auditor yang dibagi menjadi dua, yakni: skeptisisme personal dan situasional. Peneliti menggunakan desain eksperimen 2x3 faktorial antarsubjek (between subject) dengan melibatkan mahasiswa akuntansi sebagai subjek eksperimen. Hasil penelitian ini menunjukkan bahwa dalam audit, seseorang tidak hanya mengandalkan skeptisisme saja tetapi juga pengalaman mengaudit dengan klien yang sama. Pengalaman mengaudit dengan klien yang sama dapat mengurangi skeptisisme auditor professional. Hal ini didukung temuan penelitian ini dimana keputusan audit seseorang dipengaruhi oleh skeptisisme dan pengalaman mengaudit sebelumnya (CSE). 
Pengaruh skeptisisme juga menentukan dalam pengambilan keputusan. Subjek yang kurang skeptis secara personal akan cenderung terpengaruh daripada dengan yang lebih skeptis. Ketika mengevalusi bukti, subjek yang skeptis lebih memilih menentukan ekspektasi awal berupa kecurangan dibanding subjek yang kurang skeptis. Dari temuan ini, maka penting bagi auditor untuk berhati-hati dan waspada dalam menjalankan praktik audit. Meskipun mereka menemukan bahwa pengalaman audit tahun sebelumnya positif, negatif atau netral, seyogyanya auditor harus tetap mempertahankan skeptisme mereka dalam melaksanakan tugas audit.

Penelitian ini memiliki sejumlah keterbatasan. Pertama, sampel yang digunakan berasal dari mahasiswa strata satu yang bersifat homogen. Hasil serupa bisa saja ditemukan ketika penelitian diselenggarakan di kampus lain. Kedua, penelitian eksperimen tidak memprioritaskan generalisasi hasil (validitas eksternal) tetapi lebih kepada aspek kausalitas atau lebih berfokus kepada penemuan hubungan sebab akibat antar variabel (validitas internal). Karenanya, hal ini menyebabkan temuan ini tidak dapat disimpulkan untuk lingkup yang lebih luas. Penelitian selanjutnya dapat diselenggarakan untuk dapat menemukan hasil yang bisa digunakan untuk mendukung atau bahkan membantah temuan ini. Penelitian selanjutnya juga dipertimbangkan untuk menggunakan sampel auditor yang memang benar-benar memiliki pengalaman audit dengan pendekatan kuasi eksperimen sehingga dapat dilakukan dalam lingkup yang lebih lewas. Dengan demikian generalisasi hasil penelitian dapat lebih luas.

\section{DAFTAR RUJUKAN}

Adrian, A. (2013). "Pengaruh Skeptisme Profesional, Etika, Pengalaman, Dan Keahlian Audit Terhadap Ketepatan Pemberian Opini Oleh Auditor (Studi Empiris pada BPK RI Perwakilan Provinsi Riau)". Jurnal Akuntansi, 1(3).

American Institute of Certified Public Accountants (AICPA). (2003). "Auditing Fair Value Measurements and Disclosures". New York: AICPA.

Anggriawan, E. F. (2014). "Pengaruh Pengalaman Kerja, Skeptisme Profesional dan Tekanan Waktu Terhadap Kemampuan Auditor dalam Mendeteksi Fraud (Studi Empiris pada Kantor Akuntan Publik di DIY)". Nominal: Barometer Riset Akuntansi dan Manajemen, 3(2).

Astuti, D., \& Saputra, M. (2016). "Pengaruh Kompetensi, Objektivitas, Due Professional Care, Dan Skeptisisme Auditor Terhadap Kualitas Hasil Pemeriksaan (Studi pada Inspektorat Aceh)". Jurnal Administrasi Akuntansi, 5(2).

Brierley, J. A., \& Gwilliam, D. (2017). "Human Resource Management Issues in Accounting and Auditing Firms: A Research Perspective”. USA: Routledge Publishing.

Cahan, S. F., \& Sun, J. (2015). "The effect of audit experience on audit fees and audit quality". Journal of Accounting, Auditing \& Finance, 30(1), 78-100.

Carpenter, T. D., \& Reimers, J. L. (2013). "Professional skepticism: The effects of a partner's influence and the level of fraud indicators on auditors' fraud judgments and actions". Behavioral Research in Accounting, 25(2), 45-69.

Chen, Q., Kelly, K., \& Salterio, S. E. (2012). "Do changes in audit actions and attitudes consistent with increased auditor scepticism deter aggressive earnings management? An experimental investigation”. Accounting, Organizations and Society, 37(2), 95-115. 
Francis, J. R. (2011). "A framework for understanding and researching audit quality". Auditing: A journal of practice \& theory, 30(2), 125-152.

Fransiska, I. (2015). "Pengaruh Skeptisme Personal dan Client Spesific Experience Terhadap Keputusan Audit”. Simposium Nasional Akuntansi 18, 188-207.

Fuad, K. (2015). "Pengaruh Independensi, Kompetensi, dan Prosedur Audit terhadap Tanggung Jawab dalam Pendeteksian Fraud". Jurnal Dinamika Akuntansi, 7(1).

Ginintasasi, R. (2016). “About Us: Direktori File UPI”. Diambil kembali dari Direktori File UPI: file.upi.edu $>$ FIP $>$ JUR. PSIKOLOGI

Gloria. (2015). "Auditor di Indonesia Menghadapi Masalah Defisiensi Audit”. Diambil kembali dari Website Berita UGM: http://ugm.ac.id/id/berita/10875auditor.di.indonesia.hadapi.masalah.defisiensi.audit

Glover, S. M., \& Prawitt, D. F. (2014). "Enhancing auditor professional skepticism: The professional skepticism continuum”. Current Issues in Auditing, 8(2), P1-P10.

Harindahyani, S. (2017). "Realitas Materialitas Audit dalam Teori dan Praktik". Jurnal Akuntansi Bisnis, 8(1).

Herawati, N. (2015). "Application of Beneish M-Score models and data mining to detect financial fraud". Procedia-Social and Behavioral Sciences, 211, 924-930.

Hogg, M. A. (2016). "Social identity theory. In Understanding Peace and Conflict Through Social Identity Theory” (pp. 3-17). Springer International Publishing.

Hurtt, R. K., Brown-Liburd, H., Earley, C. E., \& Krishnamoorthy, G. (2013). "Research on auditor professional skepticism: Literature synthesis and opportunities for future research". Auditing: A Journal of Practice \& Theory, 32(sp1), 45-97.

Institut Akuntan Publik Indonesia (IAPI). (2011). "Standar Profesional Akuntan Publik". Jakarta: Salemba Empat.

Nahartyo, E. (2012). "Desain dan Implementasi Riset Eksperimen". Yogyakarta: UPP STIM YKPN.

Nahartyo, E. dan Intiyas Utami (2016). “Panduan Praktis Riset Eksperimen”. Jakarta: PT Indeks.

Nazaruddin, I. dan Agus Tri Basuki. (2015). "Analisis Statistik Dengan SPSS". Yogyakarta: Danisa Media.

Nikolova, N., Möllering, G., \& Reihlen, M. (2015). “Trusting as a 'leap of faith': Trustbuilding practices in client-consultant relationships". Scandinavian Journal of Management, 31(2), 232-245.

Noviyanti, S. (2008). "Skeptisme Profesional Auditor Dalam Mendeteksi Kecurangan". Jurnal Akuntansi dan Keuangan Indonesia, 5(1), 102-125.

Oktarini, K., \& Ramantha, I. W. (2016). "Pengaruh Pengalaman kerja dan Kepatuhan terhadap Kode Etik pada Kualitas Audit melalui Skeptisisme Profesional Auditor". E-Jurnal Akuntansi, 15(1), 754-783.

Permana, Y. (2015)." Pengaruh Skeptisme Profesional dan Narsisme Klien Terhadap Auditor Eksternal Atas Risiko Kecurangan”. Yogyakarta: Unpublished Skripsi S1.

Popova, V. (2013). "Exploration of Skepticism, Client-Specific Experiences, and Audit Judgements". Managerial Auditing Journal, 28, 140-160.

Quadackers, L., Groot, T., \& Wright, A. (2014). “Auditors' professional skepticism: Neutrality versus presumptive doubt". Contemporary Accounting Research, 31(3), 639-657. 
Samsonova-Taddei, A., \& Humphrey, C. (2015). "Risk and the construction of a European audit policy agenda: The case of auditor liability". Accounting, Organizations and Society, 41, 55-72.

Suryanto, R., Indriyani, Y., \& Sofyani, H. (2016). "Kemampuan Auditor dalam Mendeteksi Kecurangan”. Jurnal Akuntansi dan Investasi, 18(1), 102-118.

Waluyo, A. (2017). "Skeptisme Profesional Auditor Dalam Mendeteksi Kecurangan". Jurnal Akuntansi Bisnis, 1(1).

Yendrawati, R., \& Ragil, A. S. (2017). "Pengaruh Gender, Tekanan Ketaatan, Kompleksitas Tugas dan Pengalaman Auditor terhadap Audit Judgment”. Jurnal Aplikasi Bisnis, 11(9), 1301.

Yusrianti, H. (2015). "Pengaruh Pengalaman Audit, Beban Kerja, Task Specific Knowledge Terhadap Pendeteksian Kecurangan Laporan Keuangan (Studi pada KAP di Sumatera Bagian Selatan)". Jurnal Manajemen dan Bisnis Sriwijaya, 13(1), 55-72. 